Федорович М. Ю.

M. Yu. Fedorovich РОЛЬ СОВЕТНИКОВ В ФОРМИРОВАНИИ ПОЛИТИКО-ПРАВОВЫХ ВЗГЛЯДОВ
ИМПЕРАТОРОВ СВЯЩЕННОЙ РИМСКОЙ ИМПЕРИИ ХУІ ВЕКА

\title{
THE ROLE OF ADVISERS IN THE PROCESS OF SHAPING POLITICAL VIEWS AND LEGAL OPINIONS OF THE HOLY ROMAN EMPIRE RULERS (XVI C.)
}

Федорович Максим Юрьевич - аспирант кафедры истории древнего мира и средних веков Московского педагогического государственного университета (Россия, Москва); 119991, Москва, ул. Малая Пироговская, 1; 8-985-721-76-23. E-mail: maxfed2612@rambler.ru

Mr. Maxim Yu. Fedorovich - PhD student, Department of Ancient and Medieval History, Moscow State Pedagogical University (Russia, Moscow); 1, Malaya Pirogovskaya Str., Moscow, 119991; +7 (985) 7217623. E-mail: maxfed2612@rambler.ru

Аннотация. В статье рассматривается деятельность политических советников императоров династии Габсбургов, их политико-правовые концепции и влияние на взгляды самих императоров, а также на характер их правления. Эти деятели внесли решающий вклад в политическое развитие империи в эпоху активного межконфессионального противостояния в Западной Европе в XVI веке. Концепции универсальной монархии и религиозно-политической толерантности, выдвинутые советниками императоров, оказали влияние на политику как самой империи, так и других государств.

Summary. The paper examines the activities of political advisers to Habsburg emperors, their political views and legal opinions, and their impact both on the views of emperors and on the way they ruled the country. These political figures made a decisive contribution to the political development of the Empire in an age of religious conflicts in Western Europe ( XVI c.). Such concepts as that of a universal monarchy or of religious/political tolerance were put forward by these advisers and influenced the policies of the Holy Roman Empire and of other states.

Ключевые слова: империя, советники, Габсбурги, Швенди, Круа, Гаттинара, универсальная монархия, религиозная толерантность.

Key words: Empire, advisor, Habsburgs, Schwendi, Croy, Gattinara, universal monarchy, religious tolerance

УДК 94 (4) «04/14»

Священная Римская империя германской нации в XVI в. представляла собой конгломерат владений светских и духовных князей, свободных и имперских городов. Во главе этой сложной геополитической конструкции стояли императоры из династии Габсбургов, избиравшиеся коллегией курфюрстов. Сильная власть князей, опиравшаяся на поддержку рыцарства и городов, играла децентрализаторскую роль, ослабляя власть императора. Еще одним важнейшим фактором, способствовавшим децентрализации империи, стало появление лютеранства и других течений протестантизма, зародившихся в Германии в начале XVI столетия. Габсбурги в своей внутренней и внешней политике опирались на идеологическую поддержку ряда талантливых советников. Так, императора Карла V окружали в основном выходцы из Бургундии, Италии и Испании. Фердинанд I и Максимилиан II пользовались услугами немецких юристов, таких как Ульрих Цазий и Лазарь фон Швенди. Исходя из своих политических предпочтений, они определяли направление внешней политики монархов, создавая и разрушая политические альянсы как в Европе, так и внутри империи. По-разному они видели и разрешение конфессиональных противоречий. Если Гийом де Круа требовал решительной 
борьбы со сторонниками Лютера, то Лазарь фон Швенди советовал в своих записках императору Максимилиану II проявлять толерантное отношение к протестантам.

Влияние, оказываемое советниками на формирование политико-правовых взглядов Габсбургов, на политику и законодательство империи, прослеживается по их переписке с императорами, по многочисленным сохранившимся запискам, содержавшим основные положения их политических концепций, которые затем воплощались в реальных действиях монархов. В отечественной историографии деятельность имперских советников и их влияние на взгляды Габсбургов практически не изучены.

Императорские советники принимали весьма активное участие в процессе воспитания и образования потенциальных наследников трона. Ярким примером такого советникавоспитателя стал Гийом де Круа, сеньор де Кьевр (1458-1521), наставник юного Карла V. Он был выходцем из старинного бургундского дворянского рода, находившегося в течение нескольких столетий на службе у бургундских герцогов. Семья в целом была лояльна имперской политике Габсбургов.

В 1491 г. эрцгерцог Максимилиан, наследник императора Фридриха III, после гибели своей первой супруги Марии, последней герцогини Бургундской, взял управление этими важными владениями Габсбургов в свои руки. Он привлек к себе на службу многих представителей крупного бургундского дворянства. В их число попал и Гийом де Круа. В 1486 г. он был возведен в рыцари и получил титул сеньора де Кьевра, в 1491 г. стал рыцарем ордена Золотого Руна, а вскоре сделался имперским советником и камергером двора $[12,21]$. Он остался в Бургундии и после того как Максимилиан стал императором, уже при новом наместнике - сыне императора Филиппе Красивом. На этом посту де Кьевра стремился связать Нидерланды и Испанию через заключение брака между Филиппом и Хуаной Безумной, дочерью «католических королей» Фердинанда и Изабеллы $[4,241]$. Подобный альянс создал бы в дальнейшем мощнейшую империю, включающую Германию, Нидерланды, Испанию и колониальные владения последней. При этом сам Кьевр рассчитывал на то, что выходцы из Бургундии и в первую очередь он сам будут играть ключевую роль в политике империи. В 1504 г. Кьевр был назначен «главным управителем финансов» [13, 63]. Внезапная смерть Филиппа Красивого в 1506 г. и назначение его сестры Маргариты наместницей Нидерландов, казалось бы, прервала его политическую карьеру.

Император Максимилиан, несмотря на расхождение в политических взглядах с камергером, назначил его губернатором нидерландских земель и поставил во главе созданного регентского совета, который должен был управлять Нидерландами вплоть до совершеннолетия Карла. Гийому де Круа удалось довольно быстро подчинить своей воле остальных членов совета. Успехи, достигнутые Кьевром в управлении этой провинцией, позволили императору назначить его 27 апреля 1509 г. великим камергером эрцгерцога Карла, поручив тому дело воспитания и образования внука и наследника. Фигура де Круа, лидера бургундской партии при дворе, придала должности камергера политический вес. Как отмечал биограф Карла V К. Бранди, «до этого времени должность камердинера в руках князя Шиме была чисто придворной» $[6,42]$. Юный Карл находился практически под круглосуточным присмотром со стороны камергера, что в свою очередь практически полностью исключало какое-либо влияние на него со стороны его тетки Маргариты и деда-императора. Программа обучения наследника, составленная лично Кьевром, включала в себя помимо традиционных наук тривиума и квадривиума также чтение французских хроник на французском языке. Де Круа лично занимался с эрцгерцогом историей и литературой. Сам камергер скептически относился к обучению исключительно на латыни, так как сам плохо владел этим языком. «Он давал Карлу читать несокращенные хроники в подлиннике, причем беспрерывно на занятиях по истории связывал практические и дидактические соображения» $[11,29]$. Тем самым великий камергер пытался сформировать профранцузский курс будущей имперской политики. Также Кьевр старался привить Карлу мысль о том, что Нидерланды только временно вошли в состав империи Габсбургов. «Он смотрел на Нидерланды как на государство, полностью неза- 
висимое от Германской империи» $[7,35]$. Но главной своей задачей как воспитателя Кьевр видел социализацию будущего монарха. Он знакомил своего воспитанника с церемониалом двора, повседневными делами императора, кругом его будущих обязанностей $[11,29]$.

Вокруг чрезмерной опеки бургундца Кьевра над Карлом постоянно возникали трения между профранцузски настроенным камергером и ориентировавшейся на Англию Маргаритой. При этом нередко Кьевр находил поддержку у императора Максимилиана, который также скептически относился к союзу империи с Англией $[12,107]$. По требованию Маргариты в октябре 1513 г. в Лилле состоялось совещание, в котором участвовали император Максимилиан, Генрих VIII и король Арагона Фердинанд V. Решено было назначить комиссию наблюдателей из трех человек по одному от каждого государства. Они должны были контролировать процесс воспитания Карла и свести к минимуму влияние камергера. В состав комиссии вошли кардинал Мота, епископ Бадахоса Алонсо Манрике и Мишель Павье [6, 43]. Используя противоречия между наблюдателями, де Круа удалось фактически прекратить деятельность этой комиссии спустя несколько месяцев.

Влияние великого камергера на эрцгерцога Карла впервые публично было продемонстрировано в эпизоде с попыткой ареста испанского авантюриста дона Мануэля. Этот кастильский рыцарь, служивший в начале XVI в. при дворе Филиппа Красивого, настраивал последнего против его тестя короля Фердинанда. Он стремился таким способом возвести Филиппа на арагонский престол $[13,87]$. Но все его интриги остались безрезультатными. В 1514 г. Маргарита с согласия своего отца приказала арестовать Мануэля, обвинив его в заговоре как против короля Фердинанда, так и против императора. Тем самым проявился политический союз Испании и империи. Маргарита планировала выдать арестованного Фердинанду. Между тем дон Мануэль являлся рыцарем бургундского ордена Золотого Руна. Сюзереном этого ордена был Карл. Этим и воспользовался лидер бургундской партии. Согласно статуту ордена Золотого Руна рыцарь ордена, совершивший преступление, «не мог быть выдан никакому государству, но должен был судим капитулом данного ордена» $[12,79]$. Юный эрцгерцог решительно потребовал от Маргариты освобождения дона Мануэля. Изумляясь подобному проявлению характера, император Максимилиан приказал отпустить задержанного $[12,121]$.

Великий камергер неприязненно относился к Испании и испанцам. Он полагал, что усиление Испании повлечет за собой подрыв французского влияния в Европе, а следовательно, отрицательно скажется и на положении Нидерландов и бургундской партии. Поэтому он возражал против избрания Карла на испанский престол, но, ввиду душевной болезни его матери инфанты Хуаны, другого выхода не осталось. Прибыв в Испанию в 1518 г., Кьевр попытался приобрести владения в Испании и получить для себя и своих родственников ряд должностей. Такое поведение своего советника вызвало недовольство короля Карла и между бывшим воспитателем и его воспитанником наступило охлаждение. Вступив в 1519 г. на императорский престол, Карл начал привлекать ко двору испанцев, членов ордена Золотого Руна. «На капитуле Золотого Руна в Барселоне, где 8 кастильцев из первых семей, арагонец и неаполитанец были приняты в рыцари, Карл был настроен, по данным протоколов ордена, враждебно по отношению к мнениям и желаниям Кьевра» $[2,76]$. Карл V отстранил де Круа от реального ведения дел, но сохранил за ним должность камергера вплоть до его смерти в 1521 г. Его место занял новый главный советник императора Меркурино да Гаттинара.

В отличие от политических взглядов Гийома де Круа, о которых можно судить только по косвенным свидетельствам современников, Меркурино да Гаттинара (1465 - 1530) оставил после себя довольно четко выстроенную политико-правовую концепцию «универсальной католической монархии», основные положения которой были изложены им в целом ряде записок, адресованных императору Карлу V.

Талантливый итальянский юрист, выходец из Пьемонта, начал свою карьеру при дворе герцогини Маргариты Савойской в 1501 г. Он был высокообразованным человеком, со знанием дела оперировал историческими фактами, знал основные европейские языки. Это 
привлекало к нему многих гуманистов, с которыми он состоял в переписке. В своих письмах Эразм Роттердамский называл его «блистательным мужем» за его образованность [3, 204]. Занимая пост секретаря герцогини, Гаттинара оказывал большое влияние на политическое развитие Северной Италии в первое десятилетие XVI в. После переезда Маргариты в Бургундию в 1508 г. он получил должность президента парламента Франш-Конте, встав тем самым во главе бургундского судопроизводства. В 1518 г. на него обратил внимание император Максимилиан I, назначив его главным советником наследника престола. По замыслу императора это назначение должно было усилить команду советников будущего правителя империи, а также сократить влияние де Круа на Карла. Заняв в 1521 г. пост великого канцлера империи, Гаттинара начинает переориентацию политики габсбургской монархии. Отныне его целью, как и целью Карла V, стало возвращение Священной Римской империи характера «универсальной христианской империи», каковой она являлась во времена Карла Великого. В записке императору по случаю его коронации Гаттинара пишет: «Как до Карла Великого империя разделилась, а при нем была восстановлена, так и при вашем правлении она обречена на восстановление своего могущества» $[5,125]$. В своих записках Гаттинара ненавязчиво и аргументировано доказывал юному императору выгоды универсалистской политики. При этом у Карла складывалось представление о том, что именно он принимает важнейшие для империи решения. Доказательством тому служит записка самого императора, составленная им зимой 1524 г., в которой отразились взгляды Габсбурга на положение империи и обострившийся конфликт с Францией. В ней Карл V соглашается со своим советником и называет притязания Франции основным препятствием для осуществления планов по созданию католической империи [6, 190].

Представления Гаттинары о монархической форме правления и роли императора в Европе берут свое начало от положений римского права, в которых император являлся «господином и богом», непререкаемым авторитетом в деле государственного управления. Австрийский историк А. Колер полагал, что концепция Гаттинары следует в русле «гибеллинской традиции и опыта неустойчивого политического мира Италии» $[8,21]$. Монархия как политический институт, по мысли великого канцлера, освящена божественным Провидением. Всемирно-историческая миссия универсальной монархии заключается в охране христианского мира от враждебных ему мусульман и еретиков. Первым помощником в этой миссии для императора является папа римский как глава церкви. Католическая церковь придает власти императора законный и в то же время сакральный характер, проявляющийся в акте коронации в Риме - столице западного христианства. Империя в силу своей универсальности и единства веры объединяла различные нации под короной Габсбургов. Гаттинара считал, что центром универсальной империи должна стать Италия, а отдельные итальянские княжества и города сохранили бы свою автономию. При этом «предотвращался страх перед завоеванием, узурпацией и тиранией со стороны других народов» $[8,99]$.

Франция рассматривалась советником в качестве главного геополитического соперника империи на континенте. Французские короли сами стремились к распространению своего влияния, таким образом препятствуя созданию универсальной монархии Габсбургов. Гаттинара в своих записках выдвигал три направления внешней политики империи: борьба с Францией, заключение союза с папой и итальянскими государствами, мобилизация католического мира на борьбу с лютеранами и Османской империей $[8,176]$. Ключевым союзником в противостоянии с Францией для империи должны были стать Англия и папа.

В представлении Гаттинары фигура Карла V занимала ключевое место в деле консолидации и интеграции европейских государств и создании всемирной монархии $[5,116]$. Он видел Карла прежде всего не человеком, но символом, императором, «монархом мира». В записке императору 1522 г. он называет его «величайшим князем христианства», нуждающимся в защите юношей, которого он, Гаттинара, призван сделать великим. «Я мечтаю увидеть Вас на Вашем троне с короной, чтобы потом мог сказать: «Ныне отпущаеши раба Твоего, Господи», - высказывал свое желание советник $[12,210]$. Сам император полностью вос- 


\section{Учёные записки \\ Комсомольского-на-Амуре государственного технического университета}

принял универсалистские взгляды своего советника и придерживался их как во внешней, так и во внутренней политике вплоть до своего отречения. Расхождения между ними проявлялось прежде всего в методах осуществления этой политики. Так, после пленения Франциска I при Павии, Гаттинара настаивал на том, чтобы удерживать пленника в Италии, требуя от Франции передачи империи бургундских земель, Неаполя и Милана, а также вступления последней в антиосманскую коалицию. Однако подобный план действий встретил активное сопротивление со стороны Карла V. Император посчитал необходимым отпустить Франциска, проявить к противнику христианскую добродетель, выступив тем самым в роли доброго пастыря католического мира. Сам Карл сформулировал это так: «Чтобы простить проявленную несправедливость, я считаю более ненужным мстить; кроме того месть это дело Бога» [10, 35].

Хотя Гаттинара и получил в 1527 г. титул кардинала в качестве признания своих заслуг перед империей, он постепенно все больше отдалялся от Карла V, который уже более не нуждался в помощи канцлера и все реже обращался к нему за советом. Гаттинара несколько раз просил императора об отставке, но так и не получил ее вплоть до своей кончины в 1530 г.

Аугсбургский мир 1555 г. привел к кардинальным переменам в политике империи, в законодательстве империи. Появились и новые течения в политико-правовой мысли. При Фердинанде I и его сыне Максимилиане II шел процесс поиска межконфессионального компромисса во всех сферах жизни немецкого общества. Немалую роль в этом сыграл Лазарь фон Швенди (1522 - 1584) - активный сторонник политики религиозной толерантности.

В 1548 г. Швенди руководил работой нижнесаксонского ландтага, на котором решался вопрос о заключении мира. В своем донесении Карлу V Швенди описывал атмосферу, в которой проходили заседания: «Каждый думает только о собственном преимуществе и мало заботится об общем благе, даже находит очень часто большую радость в том, чтобы видеть своего соседа уничтоженным. Также обычно каждый поддерживает врага своего соседа, а разнузданность дворянства и военных так велика, что мало отличаются те, кто выступает «за» или «против» вашего величества. В этих землях царит величайший беспорядок и каждый делает, что хочет» [1, 58]. Миссия Швенди закончилась безрезультатно. Император Максимилиан II, активно проводивший курс политического диалога с лютеранами, нуждался в опытном советнике, который смог бы способствовать политическому сближению двух конфессий на почве единства нации. При этом император рассчитывал на усиление своей власти и влияния, как в католической, так и в лютеранской частях империи [9, 295]. Таким советником и стал Лазарь фон Швенди, отозванный из Нидерландов в 1564 г.

К открытию Шпайерского рейхстага 1570 г. Швенди представил императору проект достижения политического взаимопонимания между конфессиями, получивший название «Мемуар». Швенди, по крайней мере, еще дважды дорабатывал его в своих письмах Максимилиану II. Окончательный вариант появился в 1576 г. незадолго до смерти императора. Хотя данный проект так и не был реализован, он важен для понимания политико-правовых взглядов немецкого дворянства эпохи конфессионализации.

Швенди начинал записку с экскурса в германскую историю. На конкретных примерах он показывает стремление немцев к свободе, проявлявшееся как в борьбе германских племен с Римом, так и позднее в борьбе императоров с папством [1, 59]. Причиной начала Реформации, по мнению Швенди, в первую очередь стала политика католической церкви, направленная на эксплуатацию экономического потенциала Германии. Император Карл V не оправдал надежд протестантов, пойдя на соглашение с папой. Книгопечатание стало важным инструментом широкого распространения идей Лютера среди дворян и горожан [1, 60].

Швенди полагал, что межконфессиональное противостояние и нежелание католических князей пойти на соглашение с протестантами угрожают внешней безопасности империи. «Папа, потеряв ключевые позиции в Германии, - писал он, - стремится восстановить их посредством расширения деятельности ордена иезуитов» [1, 69]. Советник активно критиковал испанского короля Филиппа II и его политику как не соответствующую интересам импе- 
рии и подрывающую хрупкий мир в Европе $[1,68]$. По мнению Швенди, император должен стать третейским судьей в межрелигиозном споре, объединяя немецкую нацию. Он предложил реформировать рейхстаг, сделав его постоянно действующим органом и передав в его ведение вопросы формирования имперской армии и монетное дело, а также создать независимый от папы общенациональный собор, в который вошли бы как католики, так и лютеране.

Толерантность и ее воплощение в немецком обществе являлась главной идеей «Памятной записки». По мысли Швенди, только толерантное отношение к католикам и лютеранам со стороны императора и имперских сословий может укрепить империю и исключит возможность внешнего вторжения. Автор «Мемуара» выступал за сильную императорскую власть, которая способна предотвратить хаос, связанный с религиозными войнами. Швенди ратовал за политическое и правовое равенство представителей христианских конфессий и изменение отношения к лютеранам. Он считал, что толерантность в немецком обществе будет способствовать росту популярности католицизма и в дальнейшем приведет к отступлению людей от лютеранства и его исчезновению. На наш взгляд, Швенди был противником как абсолютизма на уровне империи, так и на уровне княжеств. Его идеалом являлась сословно-представительная монархия с влиятельным рейхстагом под председательством императора.

Подводя итоги, следует отметить, что политические советники Габсбургов в XVI в. являлись одними из наиболее образованных политических деятелей Европы. Многие их политические и правовые идеи и концепции были воплощены в текущей политике и законодательстве империи. Именно под влиянием советников, выступавших порой в роли воспитателей будущих монархов, в значительной степени сформировались политические и правовые взгляды самих императоров.

\section{ЛИТЕРАТУРА}

1. Aus der Denkschrift des kaiserlichen Rats Lazarus von Schwendi (1574) // Deutsche Geschichte und Darstellung. - Stuttgart, 1996. - Bd. 4. Gegenreformation und Dreißigjähriger Krieg 1555-1648. - S.58-72.

2. Brandi K. Kaiser Karl V. Werden und Schicksal einer Persönlichkeit und eines Weltreiches. Quellen und Erörterungen. - München, 1941.

3. Opus Epistolarum Des. Erasmi Roterdami. - Bd.5. 1522-1524. - Oxford, 1924.

4. Bergenroth G.A. Kaiser Karl V. Und seine Mutter Johanna // Historische Zeitschrift. - Bd. 20. - 1868. S.231-270.

5. Bosbach F. Die politische Bedeutung Karls des Großen für Karl V. // Archiv für Kulturgeschichte. - Bd. 84. - 2002. - S. 113-131.

6. Brandi K. Kaiser Karl V. Werden und Schicksal einer Persönlichkeit und eines Weltreiches. - München, 1937.

7. Delfosse L.R. Die Jugend Karls V. (Diss.) - Göttingen, 1923.

8. Kohler A. Karl V. 1500-1558. Eine Biographie. - München, 1999.

9. Lanzinner M. Friedensversicherung und politische Einheit des Reiches unter Kaiser Maximilian II. (15641576). - Göttingen, 1993.

10. Schorn-Schütte L. Karl V. Kaiser zwischen Mittelalter und Neuzeit. - München, 2000.

11. Strakosch-Grassmann G. Erziehung und Unterricht im Hause Habsburg. - Wien, 1903.

12. Walther A. Die Anfänge Karls V. - Leipzig, 1911.

13. Walther A. Die burgundischen Zentralbehörden unter Maximilian I. und Karl V. - Leipzig, 1909. 